\title{
International Banking and Cross-Border Effects of Regulation: Lessons from the Netherlands*
}

\author{
Jon Frost, ${ }^{\mathrm{a}, \mathrm{b}}$ Jakob de Haan, ${ }^{\mathrm{a}, \mathrm{c}, \mathrm{d}}$ and Neeltje van Horen ${ }^{\mathrm{a}, \mathrm{e}}$ \\ ${ }^{a}$ De Nederlandsche Bank, Amsterdam, The Netherlands \\ ${ }^{b}$ VU University, Amsterdam, The Netherlands \\ ${ }^{c}$ University of Groningen, Groningen, The Netherlands \\ ${ }^{\mathrm{d}}$ CESifo \\ ${ }^{\mathrm{e}} \mathrm{CEPR}$
}

The large and concentrated international activities of Dutch banks make the Netherlands particularly relevant for assessing the outward transmission of prudential policies. Analysis of the quarterly international claims of twenty-five Dutch banks in sixty-three countries over 2000-13 indicates that Dutch banks increase lending in countries that tighten prudential regulation. This result is driven particularly by larger banks, by banks with higher deposit ratios, by lending to advanced economies, and by lending in the post-crisis period. The result is not significant in most other subsamples. These findings suggest that banks react to changes in local prudential regulation via foreign lending - which could come either from regulatory arbitrage or from signaling effects of prudential policy on country risk. This contributes to the case for the reciprocation of macroprudential policy.

JEL Codes: F42, F44, G15, G21.

\section{Introduction}

In response to the global financial crisis, microprudential and macroprudential regulations have been tightened in most countries to

*The authors thank Linda de Zeeuw, Jairo Rivera Rozo, Pieter Stam, and Marjo de Jong for providing confidential bank data, and Henk van Kerkhoff for help with data compilation. Comments by Linda Goldberg, Claudia Buch, Matthieu Bussière, Guzel Valitova, Peter Wierts, Gertjan van der Hoeven, and an anonymous referee are gratefully acknowledged. The views expressed here are those of the authors and do not necessarily reflect those of De Nederlandsche Bank. 
strengthen the stability and resilience of the banking system (Aiyar, Calomiris, and Wieladek 2015). This, in turn, has led to a discussion about the spillover effects of regulation (see Buch and Goldberg 2017 for a review of relevant studies). The Netherlands presents a unique testing ground for analyzing the outward transmission of prudential regulation, i.e., the impact of changing prudential regulation in country $j$ on lending growth by international banks to country $j$.

The Dutch economy has a large banking sector relative to GDP (De Nederlandsche Bank 2015). After peaking at 562 percent of GDP in 2007, Dutch banking-sector assets have since fallen to around 380 percent of GDP by the end of 2015, still well above the euro-area average. The sector is very concentrated: the largest three banksING, Rabobank, and ABN Amro-hold 80 percent of overall Dutch deposits and also have dominant market shares in the mortgage and business loan markets. While foreign-owned banks hold only about 10 percent of domestic banking-sector assets in the Netherlands, several Dutch banks have significant foreign activities. Together, such foreign claims amount to over $€ 1$ trillion, or about 39 percent of Dutch banks' consolidated total assets in 2015. This share, too, has fallen since the crisis, following the acquisition and breakup of ABN Amro by a banking consortium consisting of the Royal Bank of Scotland, Santander, and Fortis in 20081 and the sale of some of the foreign business units of ING, which was required by the European Commission as a condition for state support in 2008 (see figure 1).

The Dutch banking sector has gone through some important regulatory changes over the period, most particularly after the crisis, when bank capital requirements were raised significantly and binding loan-to-value and debt-service-to-income ratios were instituted for domestic mortgages. Yet these measures were often taken contemporaneously, meaning that there is relatively little variation in the domestic prudential index. Due to this feature and the relatively limited domestic activities of foreign banks in the Dutch banking system, we do not study inward transmission, which is the focus of a number of other country chapters.

\footnotetext{
${ }^{1}$ The Dutch parts of Fortis and ABN Amro were nationalized in 2009; at the end of 2015 the Dutch government sold part of its shares to the private sector in an initial private offering. The remaining shares will-at some point-also be sold.
} 


\section{Figure 1. Foreign Activities of the Dutch Banking Sector by Geography, 2004-15}

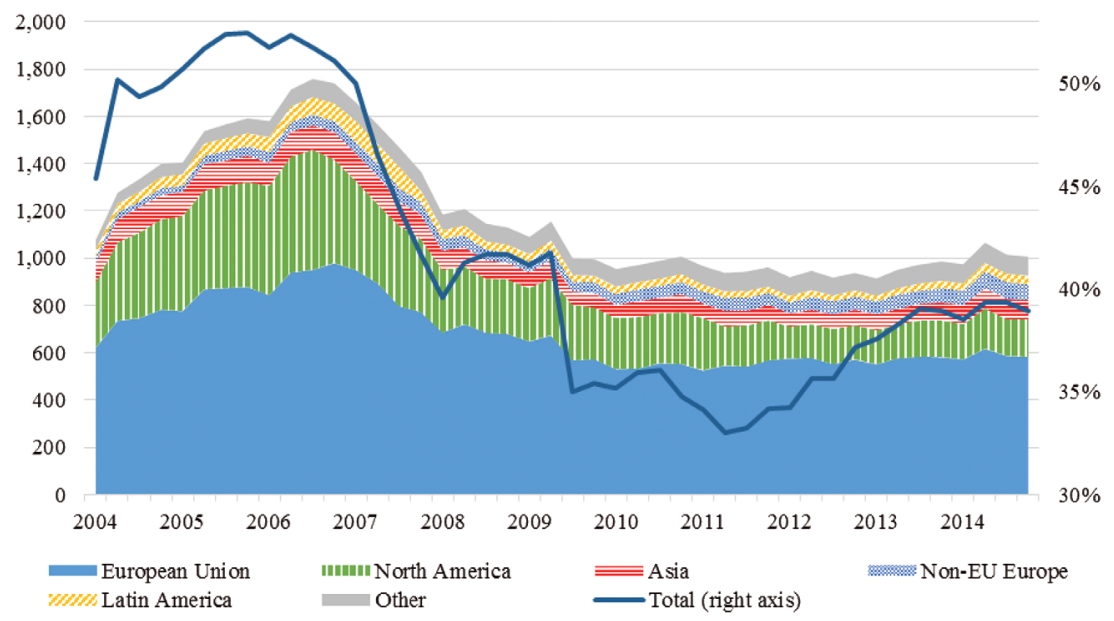

Note: The figure shows the geographical distribution of foreign activities of Dutch banks; foreign activities are defined as foreign claims of the consolidated banking sector on an ultimate-risk basis. Left axis: € billions; right axis: percentage of total assets.

Notably, the Dutch banks' foreign activities are relatively diversified. In contrast to many other national banking sectors, which often have a strong regional focus, Dutch banks have a global footprint (see chapter 10 in de Haan, Oosterloo, and Schoenmaker 2015). While the European Union (EU) accounts for 58 percent of foreign activities, Dutch banks are also active across North American, Asian, and Latin American markets. Therefore, studying the behavior of Dutch banks can provide important insights into how changes in prudential regulation in destination countries affect foreign lending activities, both cross-border and through local branches and subsidiaries. Overall, we find evidence that Dutch banks increase their foreign lending in countries that tighten prudential regulation. Looking at relevant subsamples, we find that this result is driven particularly by larger banks, by banks with higher deposit ratios, by lending to advanced economies, and by lending in the post-crisis period. The results are not significant in most other subsamples.

We offer two competing interpretations for these results. The first is that Dutch banks engage in regulatory arbitrage: when domestic 
banks in destination markets are constrained by prudential policy measures, Dutch banks, not bound by such measures, may have seen an opportunity to increase lending and gain market share. An alternative, and more benign, interpretation is that Dutch banks view the tightening of prudential measures as a positive signal about the regulatory quality of the respective country. Perceived country risk may decrease when authorities take measures to combat systemic risk, and this in turn could persuade Dutch banks' risk-management functions to increase country lending limits. For both interpretations, it is clear that the increase in lending runs counter to the intended effects of the prudential measure. As such, this supports the case for the reciprocation by the home authorities of macroprudential measures in the host country in line with recent policy initiatives in Europe (European Systemic Risk Board 2015).

The rest of this paper is organized as follows. Section 2 presents the data and stylized facts. Section 3 presents the methodology and key results in both the pooled sample and relevant subsamples. Section 4 concludes with some further discussion of the interpretation of our results and the policy implications.

\section{Data and Stylized Facts for the Netherlands}

\subsection{Bank-Level Data}

The bank-level data for this project are taken from bank-specific reporting to De Nederlandsche Bank (DNB), which acts both as the national central bank and as the prudential supervisor of the Dutch financial system (banks, insurers, pension funds, and investment funds). As a member of the Eurosystem and a reporter to the Bank for International Settlements (BIS) international banking statistics, DNB collects data using internationally comparable templates. Confidential data for twenty-five internationally active Dutch banks in sixty-three countries have been collected for the period 2000:Q1 to 2013:Q4. The data on the foreign activities of Dutch banks, necessary for the dependent variable, are taken from bank-specific reporting to DNB for the BIS international banking statistics. We use the claims on all sectors, based on the sum of crossborder lending, local lending in foreign currency, and local lending in domestic currency. These bank-specific data are accessible within 
DNB for research and policy purposes, but are not shared publicly 2 The aggregated data on such foreign claims are available on the DNB website 3 and are included in external publications of the BIS. Our dependent variable, foreign loans, captures the quarterly growth in such claims (measured by taking the log difference), i.e., $\Delta Y_{b, j, t}$ for Dutch bank $b$ in destination country $j$ in quarter $t$.

Bank balance sheet data, necessary for the construction of independent variables, come from regulatory financial reporting (FinRep) 4 These include the size of the bank captured by the log of total assets; its core deposits ratio, measured by core deposits over total assets; the unweighted tier 1 capital ratio, i.e., tier 1 capital divided by total assets, without any risk weighting; and the international activity ratio, which is defined as total foreign claims over total assets. All data are on a consolidated basis.

Table 1 offers some descriptive statistics. Across the sample, Dutch banks received only 30 percent of overall funding in the form of deposits, reflecting the relatively high use of wholesale funding. The median unweighted tier 1 capital ratio was 5 percent of total assets, and foreign activities accounted for 30 percent of the median bank's balance sheet, but with a relatively wide standard deviation. The median quarterly change in foreign activities is close to balance at 0 percent 5

Table 2 shows the correlations between the key bank-specific variables. Notably, among our sample of twenty-five Dutch banks, we see that larger banks tend to have lower deposit ratios (i.e., more wholesale funding), higher tier 1 capital ratios, and lower international

\footnotetext{
${ }^{2}$ Under certain restrictions (anonymized) micro data are available for visiting scholars for specific research projects or to replicate research results. Interested parties may contact Jakob de Haan (j.de.haan@dnb.nl).

${ }^{3}$ See http://www.dnb.nl/en/statistics/statistics-dnb/financial-institutions/ banks/consolidated-banking-statistics-supervisory/index.jsp, table 5.9, "Consolidated Assets of Domestic Credit Institutions: International Claims on Immediate Borrower Basis."

${ }^{4}$ Because the relevant reporting templates have changed over time, it has been necessary to merge the bank balance sheet time-series data from different reporting standards (2000-04, 2004-07, and 2008-13). The commitment ratio and net due to/net due from foreign office are not available in the relevant data sources.

${ }^{5}$ In line with the International Banking Research Network (IBRN) project methodology, and in order to correct for structural breaks, values of the dependent variable larger than 100 percent and smaller than -100 percent have been dropped.
} 


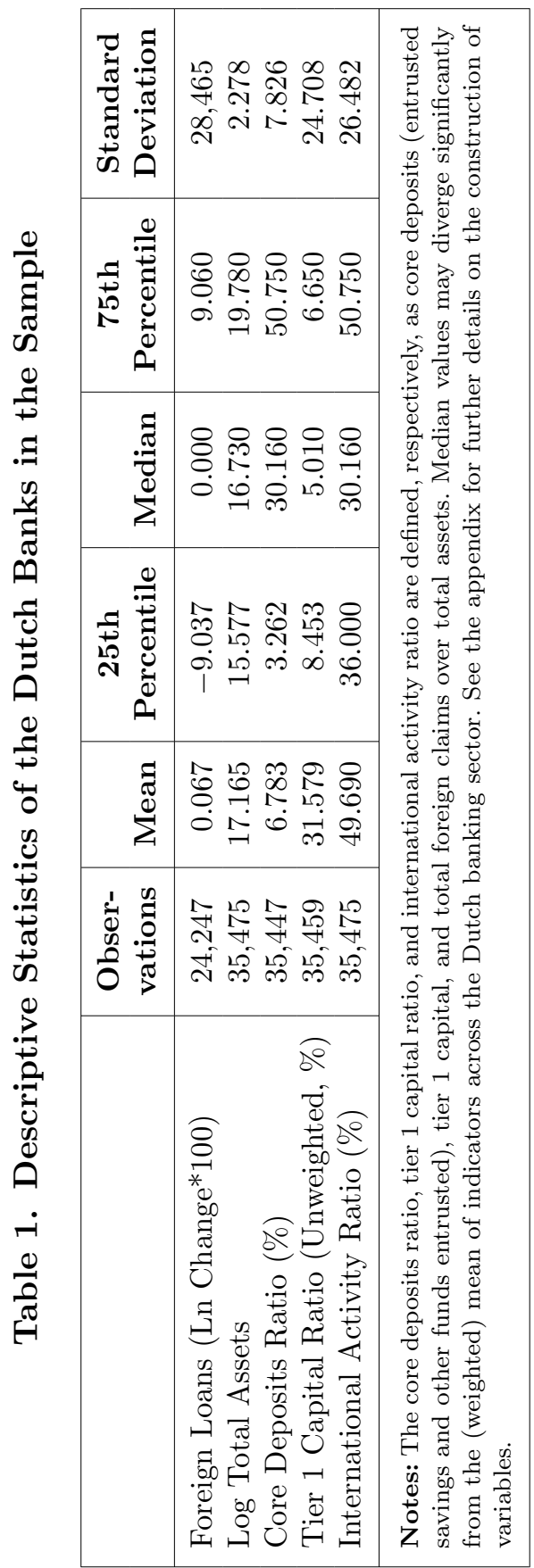




\section{Table 2. Correlations between Data on the Dutch Banks in the Sample}

\begin{tabular}{|c|c|c|c|c|}
\hline & $\begin{array}{c}\text { Log Total } \\
\text { Assets }\end{array}$ & Deposits & Tier 1 & $\begin{array}{l}\text { Inter- } \\
\text { national } \\
\text { Activity }\end{array}$ \\
\hline $\begin{array}{l}\text { Foreign Loans (Ln Change) } \\
\text { Log Total Assets } \\
\text { Core Deposits Ratio (\%) } \\
\text { Tier } 1 \text { Capital Ratio } \\
\text { (Unweighted, \%) } \\
\text { International Activity } \\
\quad \text { Ratio (\%) }\end{array}$ & 0.001 & $\begin{array}{r}0.009 \\
-0.299\end{array}$ & $\begin{array}{r}0.011 \\
0.289 \\
-0.280\end{array}$ & $\begin{array}{r}0.007 \\
-0.373 \\
0.119 \\
-0.139\end{array}$ \\
\hline \multicolumn{5}{|c|}{$\begin{array}{l}\text { Notes: The core deposits ratio, tier } 1 \text { capital ratio, and international activity ratio are } \\
\text { defined, respectively, as core deposits (entrusted savings and other funds entrusted), tier } 1 \\
\text { capital, and total foreign claims over total assets. Median values may diverge significantly } \\
\text { from the (weighted) mean of indicators across the Dutch banking sector. See table } 7 \text { in } \\
\text { the appendix for further details on the construction of variables. }\end{array}$} \\
\hline
\end{tabular}

activities (reflecting a few small banks with a very high share of activities abroad). The correlations are still low enough that the variables can be included together without any worries about multicollinearity.

\subsection{Data on Prudential Instruments}

Data for prudential instruments in destination countries draw on the IBRN Prudential Instruments Database described in Cerutti et al. (2017). As in other papers that are part of the IBRN project and that focus on outward transmission, we use "destination-country regulation" $\left(\right.$ Dest $\left._{j, t}\right)$ to capture tightening or loosening of prudential measures in destination country $j$ and time $t$. Dest $P_{j, t}$ has a value of +1 when prudential measures are tightened and -1 when measures are loosened. Over the course of the sample period there have been 419 changes in prudential regulation-both tightening and loosening - in the sixty-three countries in which Dutch banks' foreign activities are examined.

Table 3 shows the breakdown by instrument. Overall the whole sample, especially capital requirements, loan-to-value (LTV) limits on mortgages, and foreign-currency and local-currency reserve 


\section{Table 3. Summary Statistics on Changes in Prudential Instruments in Destination Countries}

\begin{tabular}{|l|c|c|}
\hline Instrument & $\begin{array}{c}\text { No. of } \\
\text { Changes } \\
\text { (Tightening) }\end{array}$ & $\begin{array}{c}\text { No. of } \\
\text { Changes } \\
\text { (Loosening) }\end{array}$ \\
\hline All Instruments & 273 & 146 \\
General Capital Requirements & 61 & 0 \\
Sector-Specific Capital Buffer & 34 & 11 \\
Loan-to-Value (LTV) Ratio Limits & 58 & 22 \\
Foreign-Currency (FX) Reserve & 65 & 37 \\
$\quad$ Requirements & 93 & 117 \\
Local-Currency (LC) Reserve & 19 & 3 \\
$\quad$ Requirements & 25 & 1 \\
Interbank Exposure Limit & & 3 \\
Concentration Ratio & & \\
\hline $\begin{array}{l}\text { Notes: Tightening (+1) refers to, e.g., an increase in capital or reserve require- } \\
\text { ments or a reduction in exposure limits; these changes make regulation more binding. }\end{array}$ \\
Moves in the other direction are loosening (-1). The "All Instruments" variable is a \\
tightening or loosening of any of the seven subcategories of instruments in a given \\
quarter.
\end{tabular}

requirements have been tightened. As an illustration, many emerging market economies tightened local-currency reserve requirements before the global financial crisis (e.g., Brazil and Turkey in 2002, China several times in 2006-08), and most advanced economies increased capital requirements at least once in 2011 and 2012. Several EU countries tightened interbank exposure limits or concentration limits during the sample period (though this data is missing for a substantial number of countries). Local-currency reserve requirements have also been loosened in a large number of cases - for example, in the euro-area countries, where the reserve requirements were lowered for all currency union members in 2000 and 2012.

\subsection{Macroeconomic and Financial Controls}

One obstacle in the analysis of Dutch banks is the relatively small number of banks active in each country. While the twenty-five banks 


\section{Figure 2. Changes in Foreign Claims after Tightening, Loosening, and Neutral Quarters}

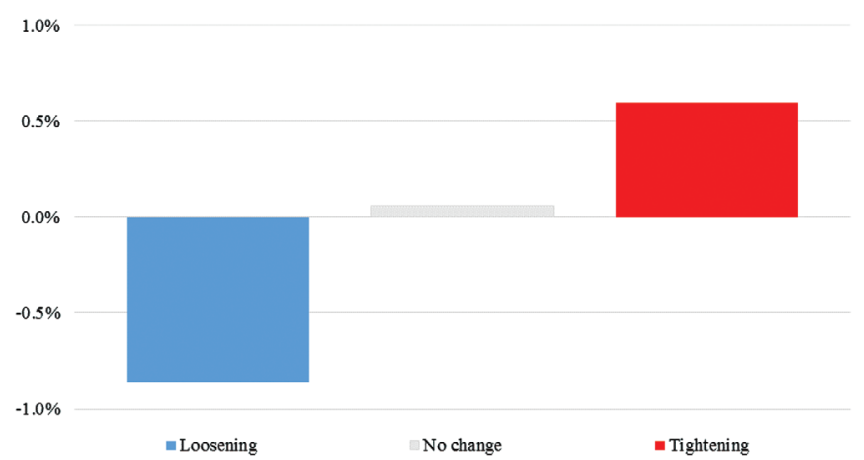

Note: The figure shows the change in foreign claims of Dutch banks after changes in prudential policies in destination countries (mean changes in the dependent variable, $\Delta Y_{b, j, t}$, in the quarter after a change in $\left.\operatorname{Dest} P_{j, t}\right)$ over the full sample.

in our sample all have foreign activities, there are significant differences between institutions. The largest banks are generally active on some scale in all of the sixty-three countries for which policy and macro data are available, while the smaller banks are in general active in only ten to twenty of the possible foreign markets. This makes it difficult to control for country-quarter effects. In order to ensure that loan demand effects and other macroeconomic factors are taken into account, we control for the business cycle using the output gap and the financial cycle using the credit-to-GDP gap as constructed by the BIS. Both measures are available at quarterly frequency.

\subsection{Stylized Facts}

An initial look at the data shows a clear result even without controlling for relevant macroeconomic and bank-specific characteristics (see figure 2). Dutch banks seem to have increased their foreign claims by about 0.6 percent within one quarter in countries which tightened prudential policy. They decreased claims by 0.86 percent within one quarter after policies were loosened. This offers a priori evidence of our key result on outward transmission. Yet notably, 
the economic relevance of this effect is relatively small-only about 0.02 standard deviations of the dependent variable. Examining this relationship while controlling for relevant macroeconomic and bankspecific characteristics is the focus of the next section.

\section{Empirical Method and Regression Results}

Following the approach to examining outward transmission described by Buch and Goldberg (2017), we use the following regression to explain how changes in prudential policies in a destination country affect changes in Dutch banks' lending growth to that country:

$$
\begin{aligned}
\Delta Y_{b, j, t}= & \alpha_{0}+\sum_{k=0}^{2} \alpha_{k+1} \operatorname{Dest}_{j, t-k}+\alpha_{4} X_{b, t-1}+\alpha_{5} Z_{j, t} \\
& +f_{j}+f_{t}+f_{b}+\varepsilon_{b, j, t},
\end{aligned}
$$

where $\Delta Y_{b, j, t}$ denotes quarterly changes in the log of claims of Dutch bank $b$ to destination country $j$ in quarter $t$. Dest $P_{j, t}, \operatorname{Dest}_{j, t-1}$, and $\operatorname{Dest}_{j, t-2}$ are changes in prudential policies in the destination country in, respectively, the current quarter, the previous quarter, and two quarters previously. Meanwhile $X_{b, t-1}$ is a vector of lagged banklevel controls, namely size tier 1 capital ratio international activity ratio and core deposits ratio; $Z_{j, t}$ is country-level controls (output gap and credit gap); and $f_{i}, f_{t}$, and $f_{b}$ are destination-country, quarter and bank fixed effects.

\subsection{Baseline Analysis of Outward Transmission of Prudential Policies}

The empirical results confirm that Dutch banks increase their activities in countries that tighten prudential regulation after one quarter. As shown in table 4 (column 1), the coefficient of all measures combined is positive and statistically significant at the 5 percent level. These findings are in line with the evidence for French banks reported by Bussière, Schmidt, and Vinas (2017), and for the foreign branches and cross-border lending of Italian banks reported by Caccavaio, Carpinelli, and Marinelli (2017). The index is not significant contemporaneously, or two quarters after the measures are 


\begin{tabular}{|c|c|c|c|c|}
\hline 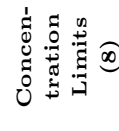 & 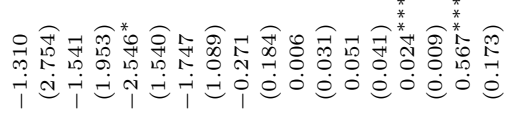 & 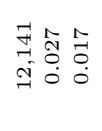 & $\begin{array}{c}\infty \\
\infty \\
\substack{\infty \\
i \\
1}\end{array}$ & 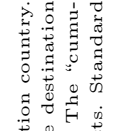 \\
\hline 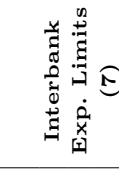 & 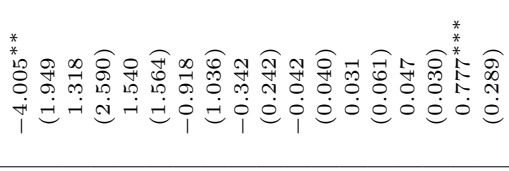 & 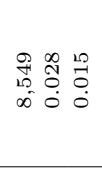 & $\begin{array}{l}\stackrel{N}{+} \\
\stackrel{+}{+} \\
\end{array}$ & 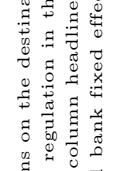 \\
\hline 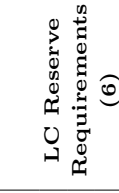 & 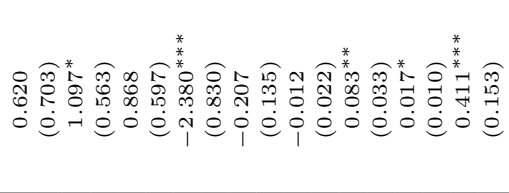 & 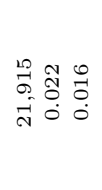 & 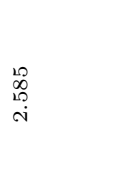 & 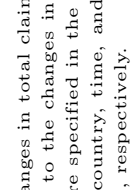 \\
\hline 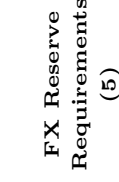 & 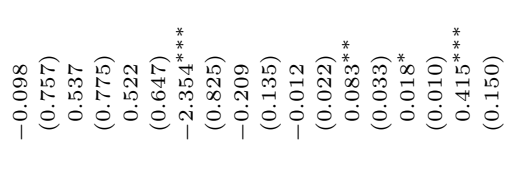 & $\begin{array}{lll}L & 0 \\
\sigma & 0 & 0 \\
\sigma & 0 \\
-1 & 0 & 0\end{array}$ & $\begin{array}{l}\text { o. } \\
\text { o } \\
0\end{array}$ & 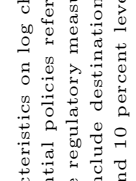 \\
\hline 勇总 & 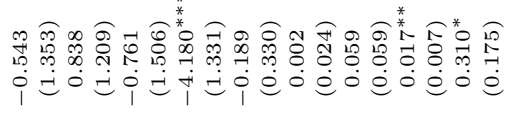 & \begin{tabular}{lll}
0 & 0 & 0 \\
$\infty$ & \multirow{1}{*}{} & 0 \\
0 & 0 \\
0 & 0 & 0 \\
0 & 0 & 0
\end{tabular} & $\begin{array}{l}0 \\
\stackrel{0}{1} \\
\stackrel{1}{0} \\
i\end{array}$ & 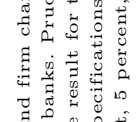 \\
\hline 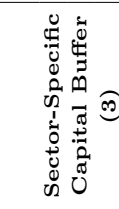 & 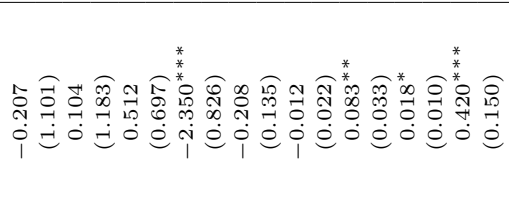 & $\begin{array}{lll}10 & 0 \\
\sigma & 0 & 0 \\
-1 & 0 \\
-1 & 0\end{array}$ & $\begin{array}{l}\stackrel{8}{+}+\frac{1}{\circ} \\
\stackrel{0}{0}\end{array}$ & 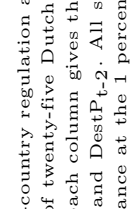 \\
\hline 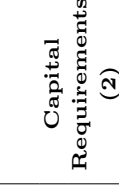 & 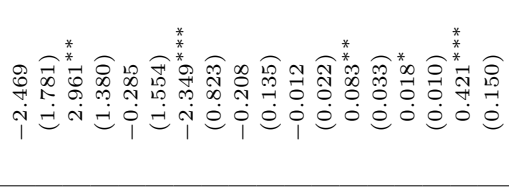 & $\begin{array}{lll}L & 0 \\
\sigma & 0 & 0 \\
-1 & 0 \\
-1 & 0 & 0\end{array}$ & $\begin{array}{l}\hat{o} \\
\text { ָे } \\
0\end{array}$ & 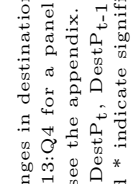 \\
\hline 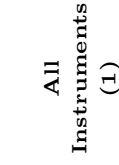 & 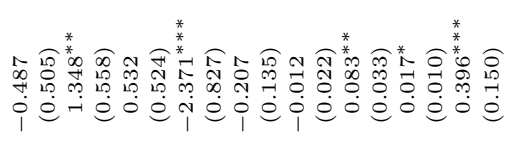 & $\begin{array}{lll}L & 0 \\
\sigma & 0 & 0 \\
0 & 0 \\
-1 & 0 & 0\end{array}$ & ભొ & 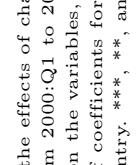 \\
\hline & 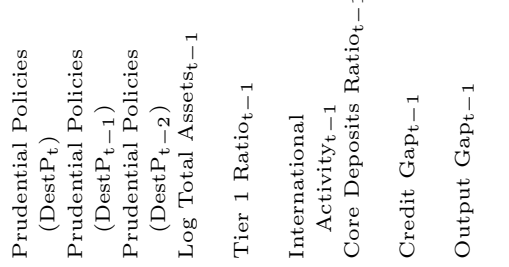 & 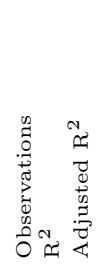 & 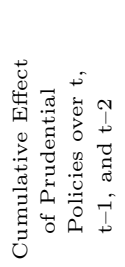 & 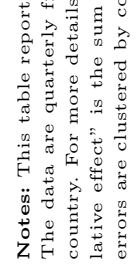 \\
\hline
\end{tabular}


taken. In economic terms, a tightening of prudential policies in one quarter leads to a 1.35 percent increase in cross-border claims one quarter later - which is about twice the size of the unconditional results reported in section 2.4, but still relatively small compared with the sample variance.

Among individual measures (columns 2-8), we find that especially increased capital requirements and local-currency (LC) reserve requirements tend to precede higher activity in the host country, again after one quarter. A tightening of capital requirements leads to an increase of 2.96 percent in international claims. Most other measures have positive coefficients after one quarter, but are not statistically significant. Interestingly, interbank exposure limits actually have a significantly negative sign during the quarter of activation, while concentration limits have a significantly negative impact two quarters later. It is possible that these instruments have been designed in ways that are binding even for foreign banks (see below).

Our findings for capital requirements are similar to results reported by Ohls, Pramor, and Tonzer (2017) and Damar and Mordel (2017) for German and Canadian banks, respectively, while our results for local-currency requirements are in line with those of Avdjiev et al. (2017) which are based on sixteen banking systems and fifty-three counterparty countries. The latter authors argue that a tightening of local-currency reserve requirements in the destination country may lead to an increase in foreign affiliates' local lending for two reasons: foreign branches are not subject to the reserve requirements of the destination country, and foreign subsidiaries (which are subject to such requirements) can obtain funding from their parent if they get close to the regulatory minimum. So foreign branches and foreign subsidiaries are likely to step in and replace domestic banks when reserve requirements increase. Likewise, foreign banks may increase cross-border lending if domestic banks reduce their lending due to increased prudential regulation. Cerutti, Claessens, and Laeven (2015) find that the greater use of macroprudential policy is associated with more reliance on cross-border credit, in particular for open economies.

Among bank controls, we find that smaller banks and those with greater deposit funding tend to have higher loan growth in foreign countries. On the other hand, the tier 1 capital ratio and 


\section{Figure 3. Schematic View of the Application of Prudential Policies}

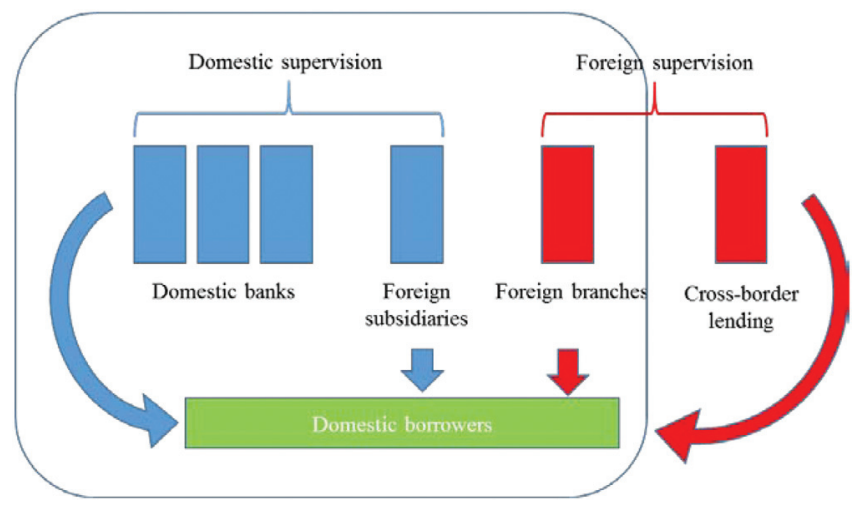

international activity ratio are not significant 6 Among the macroeconomic controls, we find - as expected - that Dutch banks tend to increase exposures in those countries where the business cycle and financial cycle are in an upturn phase 7

The results on prudential policies may be interpreted as evidence of regulatory arbitrage. Previous research on regulatory arbitrage reports that banks in countries that tighten banking regulations are induced to increase their claims on countries that are less regulated (Houston, Lin, and Ma 2012; Ongena, Popov, and Udell 2013). In our case, the story is slightly different. Because most prudential rules only apply to domestic banks and foreign subsidiaries, foreign banks active in a host country may circumvent local prudential regulation through branches and cross-border lending (figure 3). In our data set, which includes both local (branch and subsidiary) activities and

\footnotetext{
${ }^{6}$ Changes in the lag structure for bank balance sheet variables, such as lagging by two quarters, lead to a decline in significance for the coefficients of total assets and deposit funding, but not to any notable changes in the coefficient of the prudential policies variables (results available on request).

${ }^{7}$ It is possible that prudential policy variables will be determined in part based on credit market conditions - meaning an endogeneity problem with including the credit gap in our regressions. As an alternative, we have run the baseline without the credit gap. Results are very similar; only the coefficient for capital requirements loses statistical significance. Lagging the credit gap and output gap by one quarter does not lead to a change in the results (details available on request).
} 
cross-border lending 8 this would mean that Dutch banks increase their activities when domestic competitors are constrained by prudential policy. In this way, foreign banks operating through branches or direct cross-border lending can gain market share from domestic banks and foreign subsidiaries. These results are consistent with earlier studies for the United Kingdom (Aiyar, Calomiris, and Wieladek 2014; Reinhardt and Sowerbutts 2015) and with recent work on cross-sector substitution effects of macroprudential policy (Cizel et al. 2016).

An alternative, and more benign, interpretation is that Dutch banks see prudential measures as a signal of stronger regulatory quality. There is some evidence suggesting that regulatory quality is a pull factor for foreign direct investment by banks. For instance, Galindo, Micco, and Serra (2003) find that host-country banking regulations that converge toward international standards have a positive impact on foreign bank penetration. Likewise, Claessens and van Horen (2014) find that the absolute difference between homeand host-country regulation is significant in explaining bilateral foreign bank presence using a large database on 1,199 foreign banks from 75 home countries present in 110 host countries. In this case, the internal risk-management function of banks, which is responsible for setting country limits, may judge that prudential measures cause country risk to decline, or indicate a proactive stance by regulators that reflects well on overall country risk. This is consistent with the results of the controls for the output and credit gap. The fact that Dutch banks increase lending in countries experiencing strong GDP and credit growth may reflect both greater loan demand and greater risk appetite by Dutch banks in these countries. As will be discussed below, this is still problematic from a policy perspective, as it implies that banks tend to increase activities at precisely the moment that credit excesses are building up, which prudential policies are seeking to mitigate.

\footnotetext{
${ }^{8}$ Unfortunately, we are not able to distinguish between branches, subsidiaries, and cross-border lending. The breakdown that does exist in the BIS data is between cross-border lending and claims in foreign currency (i.e., domestic FX lending) on the one hand, and local claims in local currency (branches and subsidiaries) on the other. Because this conflates currency denomination with the type of bank operations, the breakdown is not useful for this analysis.
} 


\subsection{Bank Characteristics and Relevant Subsamples}

In order to better understand the link between bank characteristics and prudential policies, we split our sample along the four bank characteristics analyzed in the baseline regression: total assets, tier 1 capital ratio, international activities ratio, and deposit ratio. In each case, banks are assigned to a "high" or "low" group depending on whether they are above or below the median value across the whole sample. The regression results (table 5) show that the impact of prudential policies in the previous quarter $\left(\right.$ Dest $\left._{j, t-1}\right)$ is strongest among large banks (column 1) and those with high deposit ratios (column 7). The impact is also significant for banks with low tier 1 capital ratios (column 4) and for the subsamples with high (column 5) and low (column 6) international activities ratios.

It is difficult to gauge whether these results support the regulatory arbitrage or country risk signaling interpretation. For both narratives, large banks may be better placed than small banks to monitor changes in regulation and to respond quickly to them. Those with high deposit financing may find that they have more available liquidity to grow abroad in selected markets when opportune than banks that already depend to a large extent on wholesale funding. Yet each of these effects is possible in case of regulatory arbitrage or signaling.

As a final exercise, we also look into the results over relevant geographic and time subsamples - particularly in advanced and emerging market economies, and before and after the global financial crisis. The former are defined based on the International Monetary Fund's World Economic Outlook definition, while the break for the global financial crisis is 2008:Q1 (around the collapse of Bear Stearns, which marked a starting point for the buildup of financial market stress that culminated in September 2008 with the bankruptcy of Lehman Brothers). Table 6 shows that the coefficient for prudential policies only maintains statistical significance for advanced economies (column 1), and for the post-crisis period (column 4). It is not significant for emerging market economies (column 2) or the pre-crisis period (column 3). When splitting measures into tightening and loosening (column 5), the signs of the coefficients remain as expected: we find that tightening leads to greater cross-border lending by Dutch banks, while loosening leads to reduced lending of a roughly equal 


\begin{tabular}{|c|c|c|c|c|c|c|}
\hline 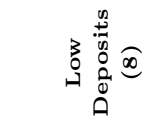 & \multicolumn{3}{|c|}{ 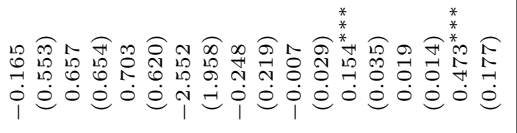 } & 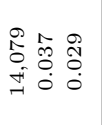 & 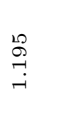 & 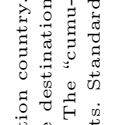 \\
\hline 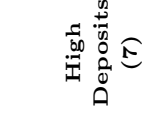 & \multicolumn{3}{|c|}{ 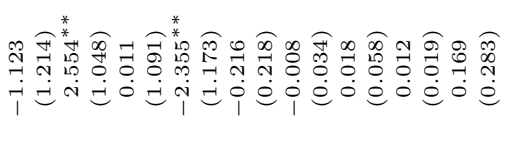 } & 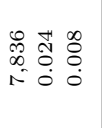 & $\underset{\stackrel{N}{+}}{\stackrel{N}{H}}$ & 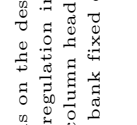 \\
\hline ق & \multicolumn{3}{|c|}{ 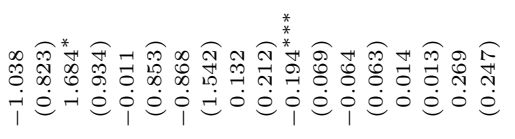 } & 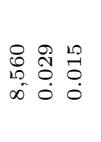 & $\begin{array}{l}\ddot{ஜ} \\
\stackrel{0}{0} \\
0\end{array}$ & 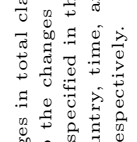 \\
\hline 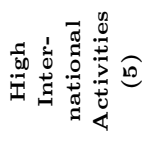 & \multicolumn{3}{|c|}{ 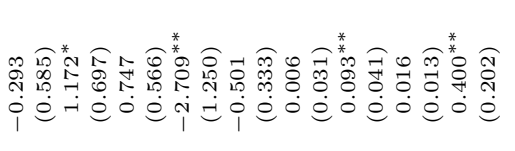 } & 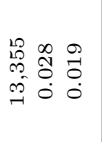 & $\begin{array}{l}\stackrel{0}{\mathscr{U}} \\
\stackrel{0}{0} \\
-i\end{array}$ & 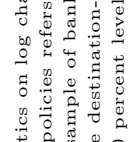 \\
\hline 葛 & \multicolumn{3}{|c|}{ 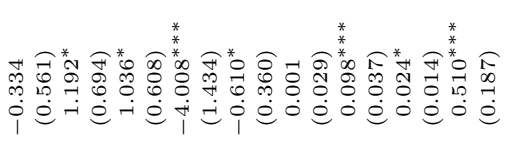 } & 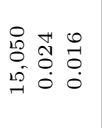 & $\begin{array}{l}\stackrel{20}{\circ} \\
\infty \\
-1 \\
-1\end{array}$ & 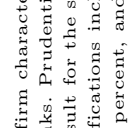 \\
\hline 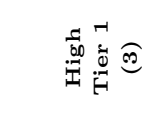 & \multicolumn{3}{|c|}{ 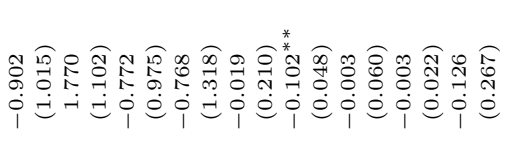 } & $\begin{array}{llll}10 & 0 & 0 \\
0 & 0 & 0 \\
0 \\
0 & 0 & 0 \\
0 & 0 & 0 \\
0\end{array}$ & $\begin{array}{l}20 \\
0 \\
0 \\
0\end{array}$ & 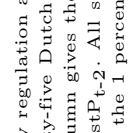 \\
\hline 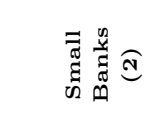 & \multicolumn{3}{|c|}{ 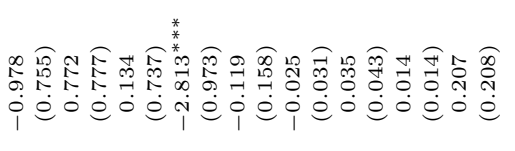 } & 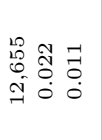 & $\begin{array}{l}\text { N } \\
0 \\
\dot{0} \\
1\end{array}$ & 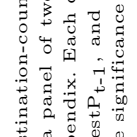 \\
\hline 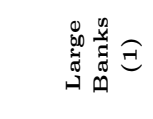 & \multicolumn{3}{|c|}{ 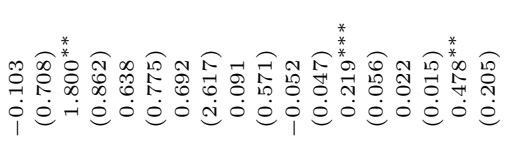 } & $\begin{array}{lll}0 & \mathbb{H} & 0 \\
0 & \mathbb{1} & 0 \\
0 \\
0 & 0 & 0 \\
0 & 0 & 0\end{array}$ & $\begin{array}{l}\stackrel{10}{\infty} \\
\text { } \\
\text { in }\end{array}$ & 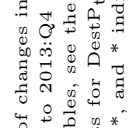 \\
\hline & 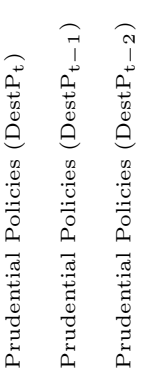 & 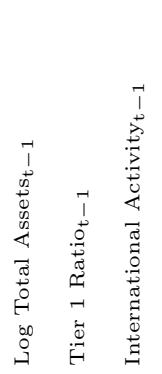 & 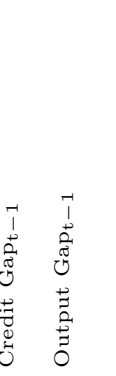 & 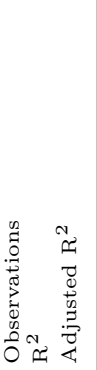 & 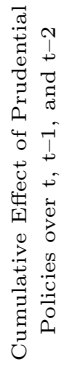 & 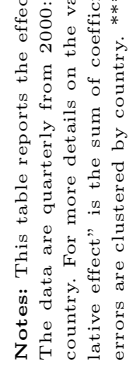 \\
\hline
\end{tabular}




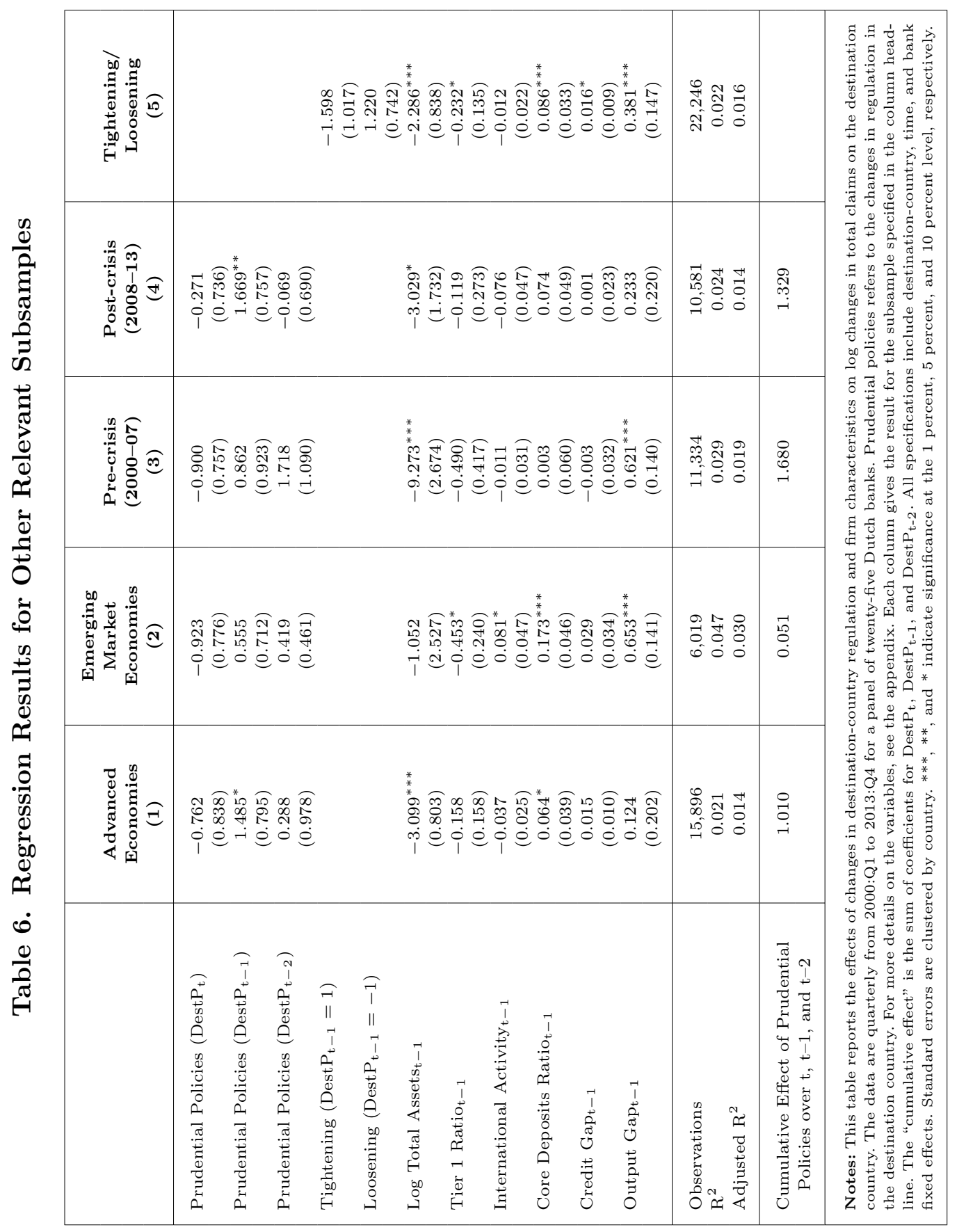


magnitude (symmetric effect). Yet with t-values of 1.57 and 1.64, both coefficients are just shy of statistical significance at the 10 percent level.

\section{Concluding Remarks}

Our results show that Dutch banks increase their local and crossborder lending in countries that tighten prudential policies, and decrease such lending after the loosening of policies. These results can be interpreted in terms of regulatory arbitrage or country risk signaling. Distinguishing between these two explanations will require further quantitative and qualitative analysis. Yet in either case, our results imply that Dutch banks have ramped up their exposures precisely when host authorities intend to put a brake on excessive lending through prudential measures. This is likely to undo part of the intended effects of the policy measures.

As such, our results support the case for reciprocation of macroprudential measures. Reciprocity means that the macroprudential authority in one country applies the measures of another jurisdiction for the activities of its banks in that jurisdiction. Right now, reciprocity of macroprudential instruments is largely voluntary and, even within the EU, has been very rare 9 The European Systemic Risk Board (ESRB) recently adopted a recommendation for a reciprocity framework in the EU, based on a "comply or explain" mechanism (ESRB 2015). This should lead to more reciprocity decisions within the EU and greater cross-country experience to build on at a global level. If reciprocity dampens the substitution of domestic credit by foreign bank lending after macroprudential measures are tightened, such a framework may contribute to greater effectiveness of macroprudential policy in the future.

\footnotetext{
${ }^{9} \mathrm{EU}$ member states may reciprocate measures of other member states based on an explicit passage in the European Capital Markets Directive and Regulation (CRD IV/CRR). Yet of the fifty substantive macroprudential measures taken in the EU in 2014, only three were voluntarily reciprocated: the Estonian systemic risk buffer (SRB), which was reciprocated by Sweden and Denmark; the Swedish countercyclical capital buffer (CCB of 1 percent), reciprocated by Denmark, Slovakia, Finland, and the United Kingdom; and the Belgian risk weights for mortgages, reciprocated by the Netherlands (DNB).
} 


\section{Table 7. Definition of Balance Sheet Independent Variables}

\begin{tabular}{|l|c|c|}
\hline Variable Name & Description & Data Source \\
\hline Log Assets & $\begin{array}{c}\text { Log (Balance Sheet } \\
\text { Total) } \\
\text { Funds Entrusted/ } \\
\text { Total Assets (in \%) }\end{array}$ & FinRep (De Nederlandsche Bank) \\
Tier 1 Capital Ratio & $\begin{array}{c}\text { Tier 1 Equity Capital/ } \\
\text { Total Assets (in \%) }\end{array}$ & FinRep (De Nederlandsche Bank) \\
International Activity & $\begin{array}{c}\text { Foreign Claims/Total } \\
\text { Assets (in \%) }\end{array}$ & $\begin{array}{c}\text { BIS Reporting and FinRep (De } \\
\text { Nederlandsche Bank) }\end{array}$ \\
\hline
\end{tabular}

\section{Appendix}

The dependent variable, $\Delta Y_{b, j, t}$, denotes the change in foreign claims by bank $b$ in destination country $b$ in quarter $t$. All values greater than 100 percent and less than -100 percent have been removed. This controls for the restructuring of certain banking groups and the sale of foreign activities in specific countries during the sample period. Data come from bank-specific reporting to DNB for the BIS international banking statistics. We use the claims on all sectors, based on the sum of cross-border lending, local lending in foreign currency, and local lending in domestic currency.

Table 7 details the construction of bank-specific variables. The ratio of illiquid assets and the net due to/due from head office are not available in the regulatory databases. All data are on a consolidated basis, and thus include the assets of foreign branches and subsidiaries as well as cross-border lending. Because reporting templates have changed during the sample period, we have merged time-series data over the periods 2000:Q1 to 2004:Q3, 2004:Q4 to 2007:Q4, and 2008:Q1 to 2013:Q4. Luckily, the definitions of our variables of interest have remained constant across the reporting templates such that they do not contribute to trend breaks. All data are reporting in (current) thousands and are not corrected for inflation or exchange rate movements. 


\section{References}

Aiyar, S., C. W. Calomiris, and T. Wieladek. 2014. "Does MacroPrudential Regulation Leak? Evidence from a UK Policy Experiment." Journal of Money, Credit and Banking 46 (s1): 181214.

- 2015. "Bank Capital Regulation: Theory, Empirics, and Policy." IMF Economic Review 63 (4): 955-83.

Avdjiev, S., C. Koch, P. McGuire, and G. von Peter. 2017. "International Prudential Policy Spillovers: A Global Perspective." International Journal of Central Banking 13 (S1).

Buch, C., and L. Goldberg. 2017. "Cross-Border Regulatory Spillovers: How Much? How Important? Evidence from the International Banking Research Network." International Journal of Central Banking 13 (S1).

Bussière, M., J. Schmidt, and F. Vinas. 2017. "International Banking and Cross-Border Effects of Regulation: Lessons from France." International Journal of Central Banking 13 (S1).

Caccavaio, M., L. Carpinelli, and G. Marinelli. 2017. "International Banking and Cross-Border Effects of Regulation: Lessons from Italy." International Journal of Central Banking 13 (S1).

Cerutti, E., S. Claessens, and L. Laeven. 2015. "The Use and Effectiveness of Macroprudential Policies." Forthcoming in Journal of Financial Stability.

Cerutti, E., R. Correa, E. Fiorentino, and E. Segalla. 2017. "Changes in Prudential Policy Instruments-A New Cross-Country Database." International Journal of Central Banking 13 (S1).

Cizel, J., J. Frost, A. Houben, and P. Wierts. 2016. "Effective Macroprudential Policy: Cross-Sector Substitution of Price and Quantity Measures." IMF Working Paper No. 16/94.

Claessens, S., and N. van Horen. 2014. "Location Decisions of Foreign Banks and Competitor Remoteness." Journal of Money, Credit and Banking 46 (1): 145-70.

Damar, H. E., and A. Mordel. 2017. "International Banking and Cross-Border Effects of Regulation: Lessons from Canada." International Journal of Central Banking 13 (S1).

de Haan, J., S. Oosterloo, and D. Schoenmaker. 2015. Financial Markets and Institutions: A European Perspective. Cambridge: Cambridge University Press. 
De Nederlandsche Bank. 2015. "Perspective on the Structure of the Dutch Banking Sector: Efficiency and Stability through Competition and Diversity." June.

European Systemic Risk Board (ESRB). 2015. "Recommendation on the Assessment of Cross-Border Effects of and Voluntary Reciprocity for Macroprudential Policy Measures." Recommendation ESRB/2015/2, December 15.

Galindo, A., A. Micco, and C. Serra. 2003. "Better the Devil that You Know: Evidence on Entry Costs Faced by Foreign Banks." Working Paper No. 477, Inter-American Development Bank.

Houston, J., C. Lin, and Y. Ma. 2012. "Regulatory Arbitrage and International Bank Flows." Journal of Finance 67 (5): 1845-95.

Ohls, J., M. Pramor, and L. Tonzer. 2017. "International Banking and Cross-Border Effects of Regulation: Lessons from Germany." International Journal of Central Banking 13 (S1).

Ongena, S., A. Popov and G. F. Udell. 2013. "When the Cat's Away the Mice Will Play': Does Regulation at Home Affect Bank Risk-Taking Abroad?" Journal of Financial Economics 108 (3): 727-50.

Reinhardt, D., and R. Sowerbutts. 2015. "Regulatory Arbitrage in Action: Evidence from Banking Flows and Macroprudential Policy." Staff Working Paper No. 546, Bank of England. 